Prepared in cooperation with the Louisiana Department of Transportation and Development

\title{
Water Resources of Jefferson Parish, Louisiana
}

\section{Introduction}

This fact sheet presents a brief overview of groundwater and surface-water resources in Jefferson Parish, Louisiana (fig. 1). Information on the availability, use, and quality of water from groundwater and surface-water sources in the parish is discussed. Previously published reports (see References Cited section) and data stored in the U.S. Geological Survey's National Water Information System (http://waterdata.usgs.gov/ nwis) are the primary sources of this information.

In 2010, about 817 million gallons per day (Mgal/d) of water were withdrawn in Jefferson Parish, approximately $810 \mathrm{Mgal} / \mathrm{d}$ from surface-water sources and approximately
7.16 Mgal/d from groundwater sources ${ }^{1}$ (table 1 ). Power generation accounted for about 91 percent of the total water withdrawn. Other water-use categories included public supply, industrial, rural domestic, livestock, and general irrigation (table 2). Water-use data collected at 5-year intervals from 1960 to 2010 (fig. 2) indicated that water withdrawals peaked at about 1,600 Mgal/d during 1975 and 1980 in Jefferson Parish. The large increase in surface-water withdrawals from 1970 to 1975 is primarily attributable to withdrawals for power generation.

${ }^{1}$ Tabulation of withdrawals in the text and tables may produce different totals because of rounding; nonrounded numbers are used for calculation of total withdrawals.
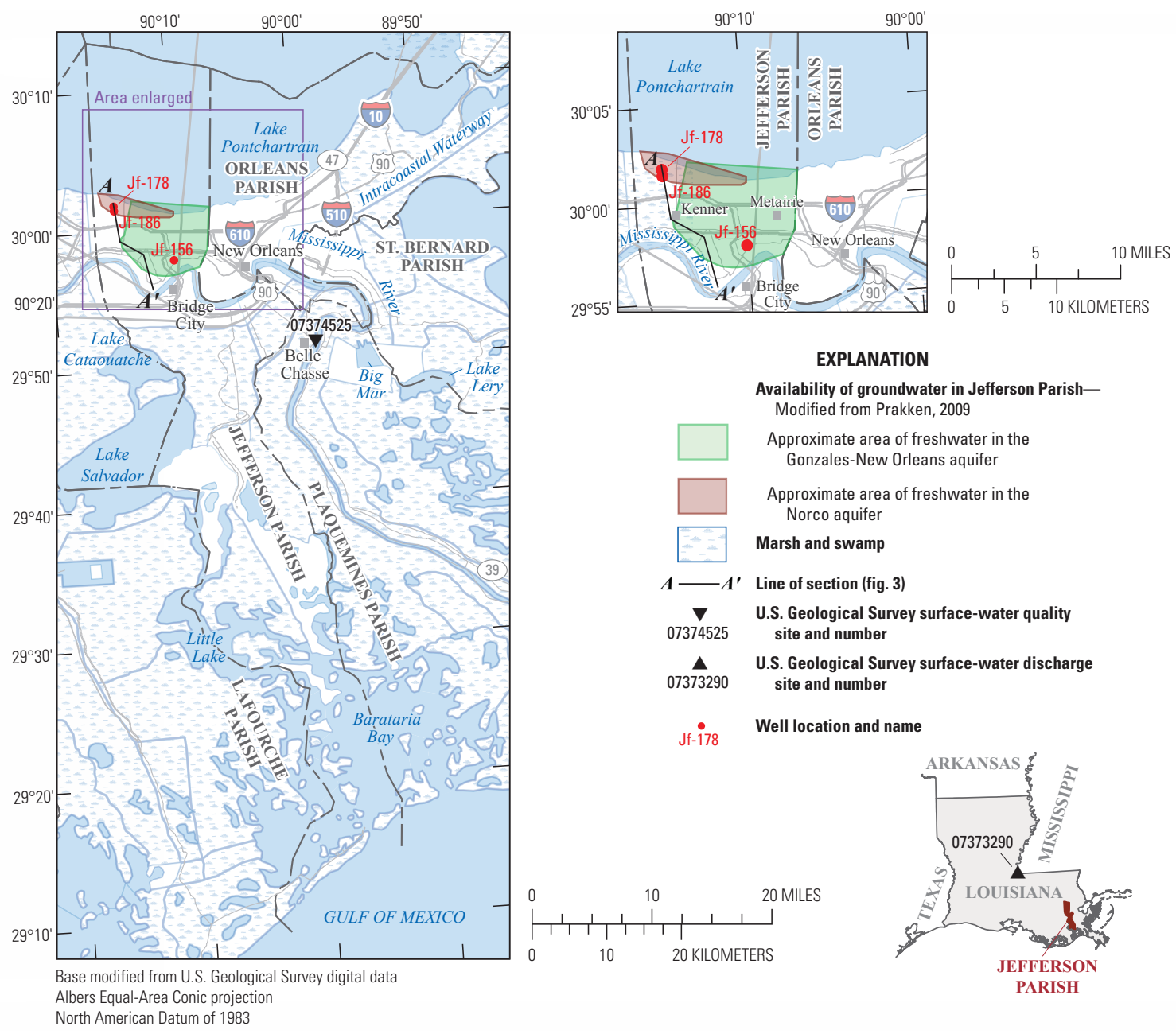

Availability of groundwater in Jefferson ParishModified from Prakken, 2009

Approximate area of freshwater in the Gonzales-New Orleans aquifer

Approximate area of freshwater in the Norco aquifer

Marsh and swamp

$A-A^{\prime}$ Line of section (fig. 3)

$\nabla \quad$ U.S. Geological Survey surface-water quality 07374525 site and number

$\Delta \quad$ U.S. Geological Survey surface-water discharge site and number

Well location and nam

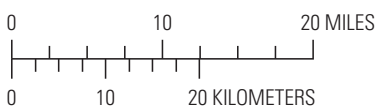

20 KILOMETERS

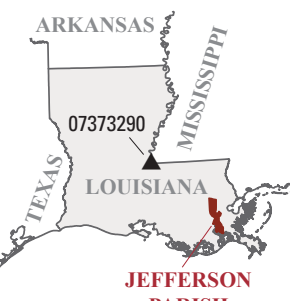

PARISH

Figure 1. Location of study area and distribution of fresh groundwater in Jefferson Parish, Louisiana. 
Table 1. Water withdrawals, in million gallons per day, by source in Jefferson Parish, Louisiana, 2010 (modified from Sargent, 2011).

\begin{tabular}{lcc}
\hline \multicolumn{1}{c}{$\begin{array}{c}\text { Aquifer or } \\
\text { surface-water body }\end{array}$} & Groundwater & Surface water \\
\hline $\begin{array}{l}\text { Mississippi River } \\
\text { point-bar deposits }\end{array}$ & 0.00 & \\
$\begin{array}{c}\text { Shallow aquifers of the } \\
\text { New Orleans area }\end{array}$ & 0.00 & \\
Gramercy aquifer & 0.02 & \\
Norco aquifer & 0.04 & 809.56 \\
Gonzales-New Orleans aquifer & 7.09 & 0.04 \\
Mississippi River & & 809.59 \\
Miscellaneous streams & 7.16 & \\
Total & & \\
\hline
\end{tabular}

Table 2. Water withdrawals, in million gallons per day, by use category in Jefferson Parish, Louisiana, 2010 (modified from Sargent, 2011).

\begin{tabular}{lccr}
\hline \multicolumn{1}{c}{ Use category } & Groundwater & Surface water & \multicolumn{1}{c}{ Total } \\
\hline Public supply & 0.00 & 64.95 & 64.95 \\
Industrial & 2.24 & 4.19 & 6.43 \\
Power generation & 4.79 & 740.42 & 745.21 \\
Rural domestic & 0.04 & 0.00 & 0.04 \\
Livestock & 0.00 & 0.04 & 0.04 \\
General irrigation & 0.08 & 0.00 & 0.08 \\
\cline { 2 - 4 } Total & 7.16 & 809.59 & 816.75 \\
\hline
\end{tabular}

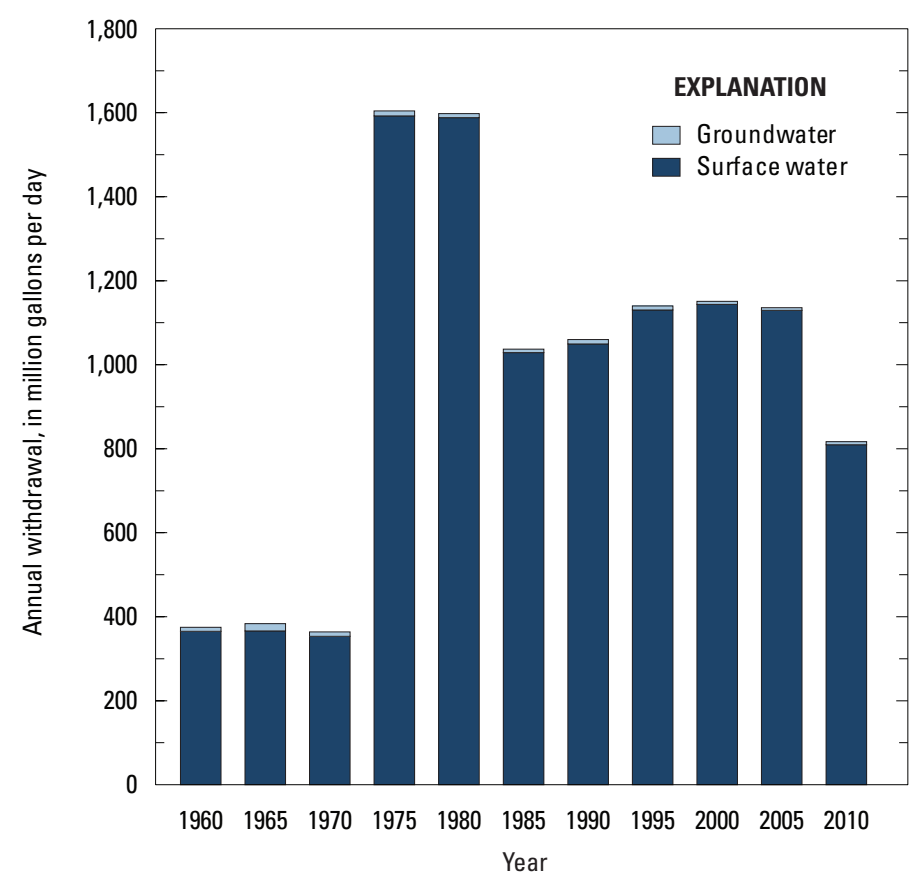

Figure 2. Water withdrawals in Jefferson Parish, Louisiana, 1960-2010 (Sargent, 2011).

\section{Groundwater Resources}

The primary groundwater resources of Jefferson Parish include the Norco and Gonzales-New Orleans aquifers (fig. 3). Other aquifers underlying the area, including Mississippi River point bar deposits, the shallow aquifers of the New Orleans area, and the Gramercy aquifer, contain very hard ${ }^{2}$ water that also has high iron concentrations (greater than 300 micrograms per liter $[\mu \mathrm{g} / \mathrm{L}]$ ) or only saltwater (water with chloride concentrations greater than 250 milligrams per liter [mg/L]). These aquifers generally are not utilized for water supply in Jefferson Parish and are not discussed further in this report (Prakken, 2009).

Recharge to aquifers in Jefferson Parish is typically by infiltration of precipitation in outcrop or subcrop areas, leakage from adjacent aquifers, and seasonal flow from rivers and canals. Discharge from aquifers is by natural flow into rivers or canals, leakage into adjacent aquifers, and withdrawals from wells. State well-registration records listed 108 active water wells in Jefferson Parish in 2009, including 50 industrial, 34 irrigation, 10 domestic, 10 public supply, and 4 power generation (Louisiana Department of Natural Resources, 2009).

\section{Norco Aquifer}

The Norco aquifer is present in most of northern Jefferson Parish, with the exception of a small area west of Metairie, but contains freshwater (water with a chloride concentration of 250 [mg/L] or less) only in a narrow strip along the Lake Pontchartrain shoreline (fig. 1). The Norco aquifer generally ranges from about 50 to 150 feet $(\mathrm{ft})$ in thickness in northern Jefferson Parish and is composed of fine to coarse sand and, possibly, fine gravel present in thin layers a few feet thick in the lower part of the aquifer (Hosman, 1972; Dial and Kilburn, 1980). A clay layer generally separates the Norco aquifer from the underlying Gonzales-New Orleans aquifer.

State well-registration data indicated that in 2009 there were 20 active wells screened in the Norco aquifer in Jefferson Parish, including 10 irrigation, 6 industrial, 3 domestic, and 1 public supply. Depths of these wells ranged from 250 to $480 \mathrm{ft}$ below land surface, with a median depth of $412.5 \mathrm{ft}$ below land surface. The records indicated that yields from wells screened in the Norco aquifer range from 3 to 2,500 gallons per minute (gal $/ \mathrm{min}$ ) (Louisiana Department of Natural Resources, 2009). In 2010, withdrawals from the Norco aquifer in Jefferson Parish totaled about $0.04 \mathrm{Mgal} / \mathrm{d}$ (table 1).

In northwestern Jefferson Parish, water levels in the Norco aquifer at well Jf-186 (fig. 1) have fluctuated from about 0 to $9 \mathrm{ft}$ below National Geodetic Vertical Datum of 1929 (NGVD 29) since 1996 (fig. 4). Freshwater in the Norco aquifer at well Jf-186 is moderately hard (Dial and Tomaszewski, 1988). The iron concentration exceeds the U.S. Environmental Protection Agency's Secondary Maximum Contaminant Level (SMCL) 3 for drinking water of $300 \mu \mathrm{g} / \mathrm{L}$ and color exceeds the SMCL of 15 platinum cobalt units. Manganese concentrations are low (less than the SMCL of $50 \mu \mathrm{g} / \mathrm{L}$ ).

${ }^{2}$ Hardness ranges, expressed as milligrams per liter of calcium carbonate, are as follows: 0-60, soft; 61-120, moderately hard; 121-180, hard; greater than 180, very hard (Hem, 1985).

${ }^{3}$ The SMCLs are nonenforceable Federal guidelines regarding cosmetic effects (such as tooth or skin discoloration) or aesthetic effects (such as taste, odor, or color) of drinking water. At high constituent concentrations and/or values, health implications as well as aesthetic degradation may be present. SMCLs were established as guidelines for the States by the U.S. Environmental Protection Agency (1992). 


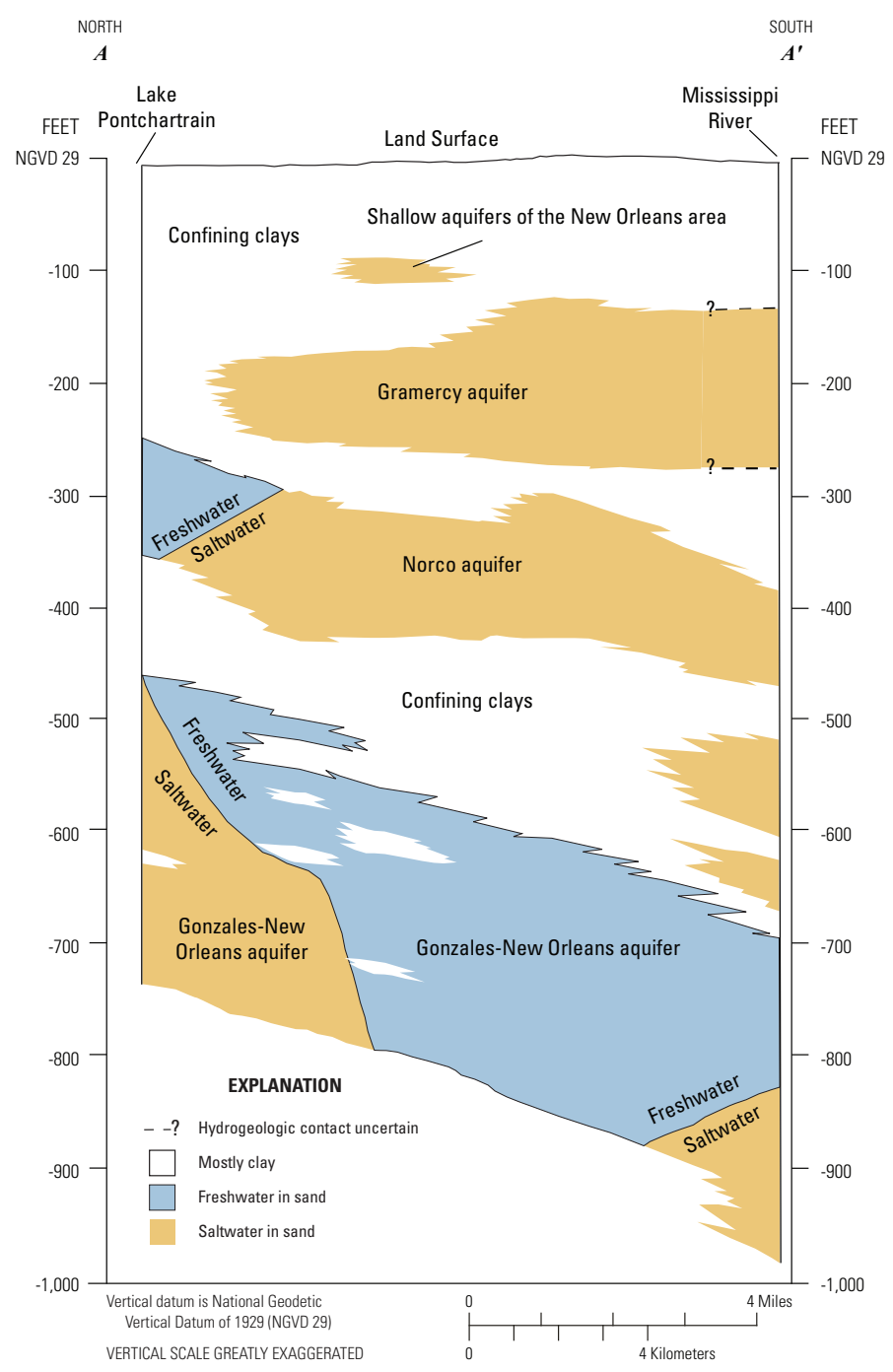

Figure 3. Generalized north-to-south hydrogeologic section through northern Jefferson Parish, Louisiana (modified from Dial and Tomaszewski, 1988). Trace of section shown on figure 1.

\section{Gonzales-New Orleans Aquifer}

The Gonzales-New Orleans aquifer is continuous throughout northern Jefferson Parish (Tomaszewski, 2003). The top of the aquifer ranges from about $500 \mathrm{ft}$ below NGVD 29 along the shore of Lake Pontchartrain to about $650 \mathrm{ft}$ below NGVD 29 near the Mississippi River. The base of the aquifer ranges from about $700 \mathrm{ft}$ below NGVD 29 near Lake Pontchartrain to about $850 \mathrm{ft}$ below NGVD 29 near the Mississippi River. The thickness of the aquifer is variable but generally is about $200 \mathrm{ft}$ (Prakken, 2009), and sand in the aquifer is fine to medium grained in northern Jefferson Parish (Dial and Tomaszewski, 1988). Fresh groundwater is present in the Gonzales-New Orleans aquifer only in parts of northern Jefferson Parish located north of the Mississippi River and east of Kenner (fig. 1). The aquifer generally contains saltwater south of the Mississippi River and in northwestern Jefferson Parish.

State well registration records listed 54 active water wells screened in the Gonzales-New Orleans aquifer in Jefferson Parish in 2009, including 36 industrial, 10 irrigation, 4 power generation, 3 public supply, and 1 domestic. Depths of these wells ranged from 557 to $878 \mathrm{ft}$ below land surface with a median depth of $764 \mathrm{ft}$. The records indicated that yields from wells screened in the Gonzales-New Orleans aquifer range from 20 to 2,400 gal/min (Louisiana Department of Natural Resources, 2009). In 2010, groundwater withdrawals from the Gonzales-New Orleans aquifer in Jefferson Parish totaled about 7.09 Mgal/d (table 1) and included 2.24 Mgal/d for industrial, $4.79 \mathrm{Mgal} / \mathrm{d}$ for power generation, $0.01 \mathrm{Mgal} / \mathrm{d}$ for rural domestic, and $0.04 \mathrm{Mgal} / \mathrm{d}$ for general irrigation.

In 2008, there were two major water withdrawal centers in the parish: one center was located about $1 \mathrm{mi}$ southwest of Bridge City (about $1.8 \mathrm{Mgal} / \mathrm{d}$ withdrawn in 2007), and the other center was located about $1 \mathrm{mi}$ northeast of Bridge City (an estimated 3.9 Mgal/d withdrawn in 2007). The Gonzales-

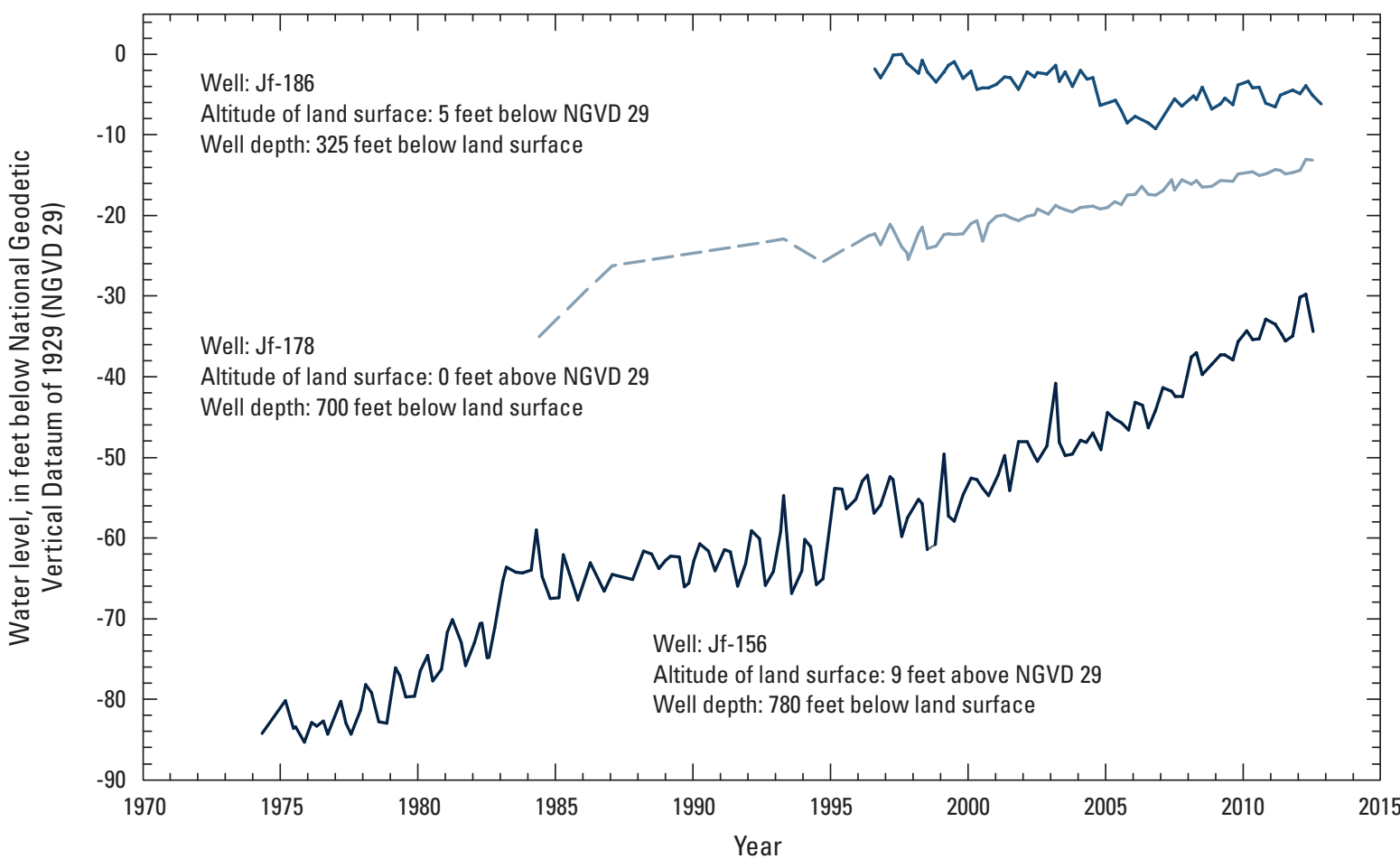

Figure 4. Water levels in well Jf-186 screened in the Norco aquifer and wells Jf-156 and Jf-178 screened in the Gonzales-New Orleans aquifer in Jefferson Parish, Louisiana (see fig. 1 for well locations; U.S. Geological Survey, 2012). Land surface is measured in feet above the National Geodetic Vertical Datum of 1929 (NGVD 29). 
New Orleans aquifer produced saltwater at both of these centers (Prakken, 2009). In 2008, water levels in the GonzalesNew Orleans aquifer generally ranged from about $16 \mathrm{ft}$ below NGVD 29 in northwestern Jefferson Parish to about $47 \mathrm{ft}$ below NGVD 29 near Bridge City. The general direction of flow in the Gonzales-New Orleans aquifer north of the Mississippi River was toward the east-southeast (Prakken, 2009).

Water levels in the aquifer generally have risen since the 1970 s in response to reduced withdrawals. Water levels in the Gonzales-New Orleans aquifer at well Jf-156, located north of Bridge City and the Mississippi River (fig. 1), have risen about $49 \mathrm{ft}$ since the mid 1970s (fig. 4). Water levels in well Jf-178, located in northwestern Jefferson Parish along the shore of Lake Pontchartrain (fig. 1), have risen about $10 \mathrm{ft}$ since 1997 (fig. 4).

A statistical summary of selected water-quality characteristics for freshwater samples from 28 wells screened in the Gonzales-New Orleans aquifer is listed in table 3. Based on median values of chemical constituents, freshwater from the aquifer is generally soft and generally does not exceed SMCLs for drinking water for $\mathrm{pH}$ and concentrations of iron and manganese. Dissolved solids concentrations are generally less than the SMCL of $500 \mathrm{mg} / \mathrm{L}$ but locally may exceed this level. Freshwater in the aquifer has a yellow color and exceeds the SMCL of 15 platinum cobalt units.

\section{Surface-Water Resources}

The Mississippi River is the primary source of fresh surface water in Jefferson Parish (table 1). In 2010, about $810 \mathrm{Mgal} / \mathrm{d}$ of surface water were withdrawn from the Mississippi River in the parish, including about $65.0 \mathrm{Mgal} / \mathrm{d}$ for public-supply, 4.19 Mgal/d for industrial use, and $740 \mathrm{Mgal} / \mathrm{d}$ for power generation. Most surface water withdrawn for power generation is used for cooling purposes and is returned to its source after use (Sargent, 2011). In 2010, about $0.04 \mathrm{Mgal} / \mathrm{d}$ were withdrawn in Jefferson Parish from miscellaneous streams for livestock. Notable surfacewater bodies in or bordering Jefferson Parish include Lake Pontchartrain, Lake Cataouatche, Lake Salvador, Little Lake, Barataria Bay, and the Gulf of Mexico (fig. 1). There were no reported withdrawals from these sources in 2010.

Water samples collected and analyzed during 1977-2009 indicated that water in the Mississippi River at Belle Chasse (fig. 1) is generally hard and generally does not exceed the SMCLs for $\mathrm{pH}$ and concentrations of chloride, sulfate, and iron (table 4). Dissolved oxygen concentration is generally greater than $5 \mathrm{mg} / \mathrm{L}$, which is considered the minimum value for a diversified population of fresh, warmwater biota, including sport fish (Louisiana Department of Environmental Quality, 2008). Mississippi River discharge data are not available for Jefferson Parish, but the average flow of the Mississippi River near Red River Landing, about 200 river miles upstream of the parish (fig. 1, index map), was about 460,000 cubic feet per second (about 298,000 Mgal/d) during the period 1928-76 (Wells, 1980). The flow in the Mississippi River at Red River Landing (07373290) is representative of flows in Jefferson Parish because there are no major tributaries or distributaries, and the river is mostly leveed between the landing and the parish.

Table 3. Summary of selected water-quality characteristics for freshwater in the Gonzales-New Orleans aquifer in Jefferson Parish, Louisiana, 1940-2008 (U.S. Geological Survey, 2009).

[Values are in milligrams per liter, except as noted. ${ }^{\circ} \mathrm{C}$, degrees Celsius; $\mathrm{PCU}$, platinum cobalt units; $\mu \mathrm{S} / \mathrm{cm}$, microsiemens per centimeter; $\mathrm{SU}$, standard units; $\mathrm{CaCO}_{3}$, calcium carbonate; $\mu \mathrm{g} / \mathrm{L}$, micrograms per liter; SMCL, Secondary Maximum Contaminant Level established by the U.S. Environmental Protection Agency, (2012); NA, not applicable]

\begin{tabular}{|c|c|c|c|c|c|c|c|c|c|}
\hline & $\begin{array}{c}\text { Temperature } \\
\left({ }^{\circ} \mathrm{C}\right)\end{array}$ & $\begin{array}{l}\text { Color } \\
\text { (PCU) }\end{array}$ & $\begin{array}{c}\text { Specific } \\
\text { conductance, } \\
\text { field } \\
\left(\mu \mathrm{S} / \mathrm{cm} \text { at } 25^{\circ} \mathrm{C}\right)\end{array}$ & $\begin{array}{l}\mathrm{pH}, \\
\text { field } \\
\text { (SU) }\end{array}$ & $\begin{array}{l}\text { Hardness } \\
\text { (as } \mathrm{CaCO}_{3} \text { ) }\end{array}$ & $\begin{array}{c}\text { Chloride, } \\
\text { filtered } \\
\text { (as CI) }\end{array}$ & $\begin{array}{c}\text { Iron, } \\
\text { filtered } \\
\text { ( } \mu \mathrm{g} / \mathrm{L} \text { as } \\
\mathrm{Fe})\end{array}$ & $\begin{array}{c}\text { Manganese, } \\
\text { filtered } \\
\text { ( } \mu \mathrm{g} / \mathrm{L} \text { as } \mathrm{Mn} \text { ) }\end{array}$ & $\begin{array}{l}\text { Dissolved } \\
\text { solids, } \\
\text { filtered }\end{array}$ \\
\hline \multicolumn{10}{|c|}{ Gonzales-New Orleans aquifer (28 wells) } \\
\hline Median & 25.0 & 100 & 786 & 8.3 & 16 & 88 & 80 & 20 & 422 \\
\hline 90th percentile & 25.5 & 190 & 976 & 8.5 & 26 & 120 & 120 & 30 & 544 \\
\hline Number of samples & 21 & 22 & 20 & 21 & 22 & 28 & 10 & 10 & 14 \\
\hline $\begin{array}{l}\text { Percentage of } \\
\text { samples that do not } \\
\text { exceed SMCLs }\end{array}$ & NA & 0 & NA & 90 & NA & 100 & 90 & 100 & 71 \\
\hline
\end{tabular}


Table 4. Summary of selected water-quality characteristics for the Mississippi River at Belle Chasse, Louisiana, 1977-2009.

[Values are in milligrams per liter, except as noted. $\mu \mathrm{S} / \mathrm{cm}$, microsiemens per centimeter; ${ }^{\circ} \mathrm{C}$, degrees Celsius; $\mathrm{SU}$, standard units; $\mathrm{CaCO}_{3}$, calcium carbonate; $\mu \mathrm{g} / \mathrm{L}$, micrograms per liter; <, less than; SMCL, Secondary Maximum Contaminant Level established by the U.S. Environmental Protection Agency (2012); NA, not applicable]

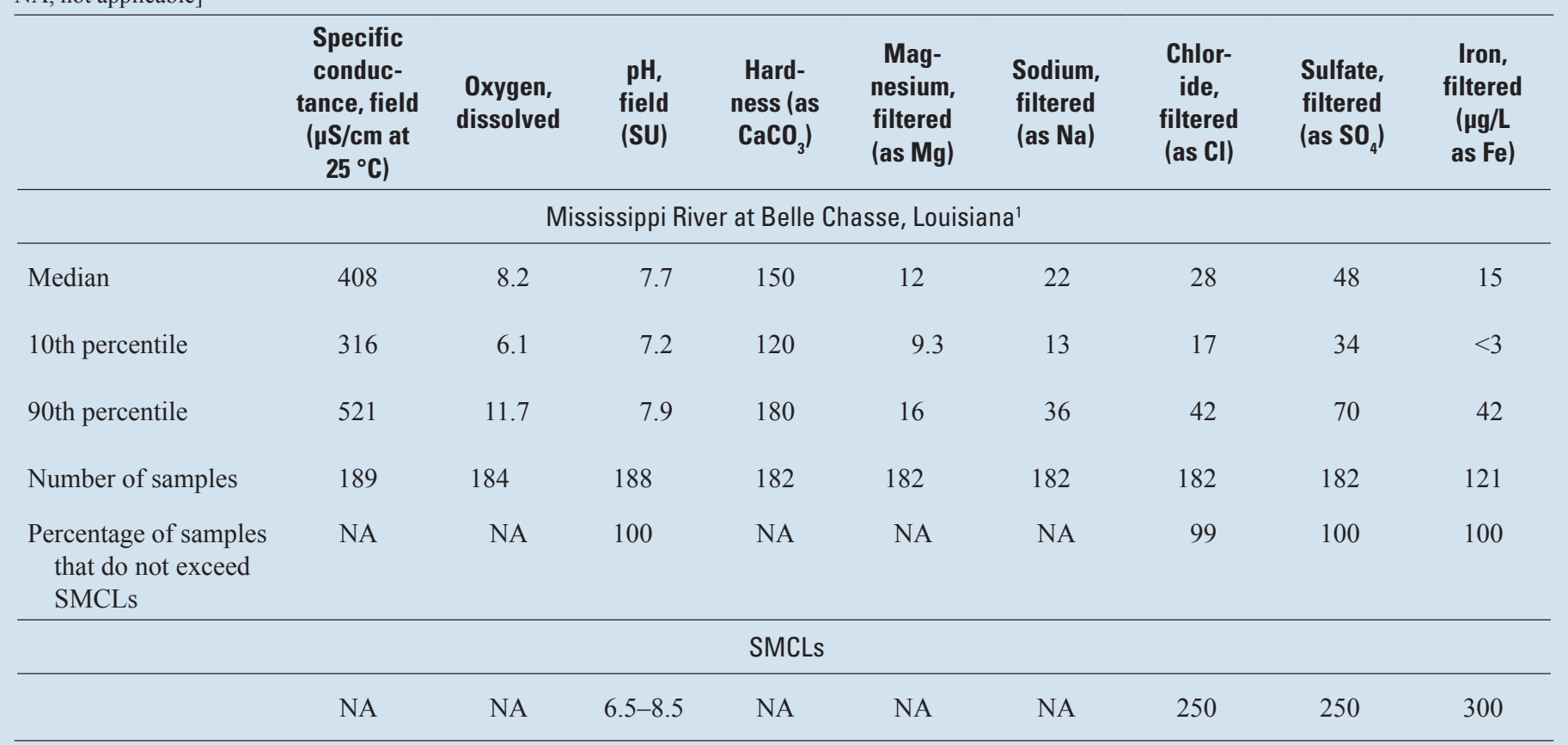

${ }^{1}$ Station number 07374525 (U.S. Geological Survey, 2009; specific data at http://nwis.waterdata.usgs.gov/la/nwis/qwdata/?site_no=07374525).

\section{References Cited}

Dial, D.C., 1983, Ground-water data for the Mississippi River parishes in the greater New Orleans area, Louisiana: Louisiana Department of Transportation and Development, Office of Public Works Water Resources Basic Records Report no. 11, 47 p.

Dial, D.C., and Kilburn, Chabot, 1980, Ground-water resources of the Gramercy area, Louisiana: Louisiana Department of Transportation and Development, Office of Public Works Water Resources Technical Report no. 24, 39 p.

Dial, D.C., and Tomaszewski, D.J., 1988, Geohydrology, water quality, and effects of pumpage on the New Orleans aquifer system, northern Jefferson Parish, Louisiana: U.S. Geological Survey Water-Resources Investigations Report 88-4097, 34 p., accessed August 6, 2012, at http://pubs.usgs.gov/ wri/1988/4097/report.pdf.

Hem, J.D., 1985, Study and interpretation of the chemical characteristics of natural water (3d ed.): U.S. Geological Survey Water-Supply Paper 2254, 264 p., accessed February 20, 2013, at http://pubs.er.usgs.gov/publication/wsp2254.

Hosman, R.L., 1972, Ground-water resources of the Norco area, Louisiana: Department of Conservation, Louisiana Geological Survey, and Louisiana Department of Public Works Water Resources Bulletin no. 18, 61 p.
Louisiana Department of Environmental Quality, 2008, Environmental Regulatory Code, Title 33, Part IX, Subpart 1, accessed June 9, 2009, at http:www.deq.louisiana.gov/portal/ tabid/1674/Default.aspx.

Louisiana Department of Natural Resources, 2009, Strategic Online Natural Resources Information System (SONRIS): Louisiana Department of Natural Resources database, accessed July 1, 2009, at http://sonris.com/.

Prakken, L.B., 2009, Groundwater resources in the New Orleans area, 2008: Louisiana Department of Transportation and Development Water Resources Technical Report no. 80, $36 \mathrm{p}$.

Sargent, B.P., 2011, Water use in Louisiana, 2010: Louisiana Department of Transportation and Development Water Resources Special Report no. 17, 135 p.

Tomaszewski, D.J., 2003, Ground-water resources along the lower Mississippi River, southeastern Louisiana: Louisiana Department of Transportation and Development Water Resources Technical Report no. 69, 23 p.

U.S. Environmental Protection Agency, 1992, Secondary Drinking Water Regulations - Guidance for nuisance chemicals: U.S. Environmental Protection Agency publication EPA 810/K-92-001, 4 p., accessed September 28, 2011, at http://water.epa.gov/drink/contaminants/ secondarystandards.cfm. 
U.S. Environmental Protection Agency, 2012, 2012 Edition of the drinking water standards and health advisories: U.S. Environmental Protection Agency publication EPA 822-S12-001, Office of Water, 12 p., accessed August 7, 2012, at http://water.epa.gov/action/advisories/drinking/upload/ dwstandards2012.pdf.

U.S. Geological Survey, 2009, Water quality samples for Louisiana: National Water Information System Web Interface, accessed June 2, 2009, at http://nwis.waterdata.usgs.gov/la/ nwis/qwdata.

U.S. Geological Survey, 2012, Groundwater levels for Louisiana: National Water Information System Web Interface, accessed August 6, 2012, at http://nwis.waterdata.usgs.gov/la/ nwis/gwlevels.

Wells, F.C., 1980, Hydrology and water quality of the lower Mississippi River: Louisiana Department of Transportation and Development, Office of Public Works Water Resources Technical Report no. 21, 83 p.

This fact sheet was published by the U.S. Geological Survey, in cooperation with the Louisiana Department of Transportation and Development (DOTD). Thanks are given to Zahir "Bo" Bolourchi, Director, Water Resources Programs, Louisiana Department of Transportation and Development, who contributed to the content of the fact sheet.

\section{By Lawrence B. Prakken and John K. Lovelace}

\section{For additional information, contact:}

Director, USGS Louisiana Water Science Center 3535 S. Sherwood Forest Blvd., Suite 120

Baton Rouge, LA 70816

E-mail: dc_la@usgs.gov

Fax: (225) 298-5490

Telephone: (225) 298-5481

Home Page: http://la.water.usgs.gov 